В.Л. Орленко, А.С. Сфімов, К.Ю. Іваськіва

\title{
ДОСВІД ЗАСТОСУВАННЯ ПРЕПАРАТІВ ГЕННОІНЖЕНЕРНИХ ІНСУЛІНІВ ВИРОБНИЦТВА КОМПАНІЇ «ФАРМАК» У ХВОРИХ НА ЦУКРОВИЙ ДІАБЕТ 2-ГО ТИПУ
}

\author{
ДУ «Інститут ендокринологї та обміну речовин ім. В.П. Комісаренка НАМН України», Київ
}

Однією з актуальних і важливих соціальноекономічних проблем клінічної ендокринології $\epsilon$ цукровий діабет (ЦД). Це захворювання належить до пріоритетних у клінічній ендокринології, адже, за визначенням ВООЗ, ЦД називають неінфекційною епідемією XXI століття. В економічно розвинутих країнах світу 4-6\% людей хворіють на ЦД. За прогнозами ВООЗ, до 2030 року кількість хворих на ЦД у світі може збільшитись до 552 млн. [1].

В Україні захворюваність на цукровий діабет, як і в інших країнах світу, теж щорічно зростає, наразі налічується понад 1,2 млн. хворих на ЦД. Але наведені дані не відображають істинної розповсюдженості захворювання. Чітко показано, що поряд із кожним зареєстрованим $€ 2$ 2-3 недіагностованих хворих, причому це стосується в основному хворих на ЦД 2-го типу [2]. Високому рівню захворюваності на ЦД сприяють багато чинників, серед яких головне місце посідають особливості харчування, надмірні стресові впливи, низька фізична активність, що призводять до розвитку метаболічного синдрому, одним із компонентів якого $\epsilon$ порушена толерантність до глюкози або цукровий діабет 2-го типу в поєднанні 3 гіперліпідемією, гіпертонією, ожирінням [3, 4].

Однією з актуальних нині в Україні проблем $\epsilon$ рівень компенсації захворювання у пацієнтів із ЦД 2-го типу. За орієнтовними даними, компенсованими є лише 10-15\% хворих на ЦД 2-го типу. Однією із суттєвих причин такого стану $\epsilon$ пізнє призначення інсулінів. Мета-аналіз багатоцентрових досліджень (ACCORD, ADVANS, UKPDS, VARD) показав, що вчасний початок інсулінотерапії забезпечує оптимальний контроль глікемії та, відповідно, поліпшує прогноз, уповільнюючи розвиток хронічних ускладнень ЦД. Тобто, інсулінотерапія у хворих із ЦД 2-го типу має призначатися вчасно та вчасно інтенсифікуватися. За даними [5], кількість пацієнтів із ЦД 2-го типу, яким вчасно вперше призначається інсулін, складає лише 5\%. У середньому інсулін таким хворим призначається через 8 років із моменту встановлення діагнозу.
В українському дослідженні CREDIT за участю 149 пацієнтів із ЦД 2-го типу показано поліпшення всіх параметрів глікемічного контролю після переходу на інсулінотерапію, а у $26 \%$ випадків вдалося досягти рівня глікованого гемоглобіну менше від 7\% (вихідний - 10,1\%). У міру прогресування ЦД захворюванням важче управляти; у цьому плані інсулін дає додаткові переваги, оскільки його дія не залежить від залишкової секреторною активності бета-клітин [6, 7].

Часто і пацієнти, і лікарі уникають призначення інсуліну через побоювання гіпоглікемії та невірне тлумачення сенсу інсулінотерапії, що призводить до тривалого періоду декомпенсації й збільшення ризику розвитку мікро- та макросудинних ускладнень [8]. Основними бар'єрами на шляху старту інсулінотерапії $\epsilon$ : ризик розвитку гіпоглікемій і збільшення маси тіла, виникнення додаткових незручностей від виконання ін'єкцій та ускладнення режиму дня.

Отже, сучасний алгоритм лікування ЦД 2-го типу передбачає відносно ранній початок інсулінотерапії за неможливості досягнення компенсації ЦД на максимальних дозах пероральних цукрознижувальних препаратах, що можна вважати оптимальним підходом, який дозволяє, зокрема, зменшити негативні наслідки декомпенсації ЦД стосовно розвитку макро- та мікросудинних ускладнень $[9,10]$.

Останніми роками відбулися зміни у підходах до інсулінотерапії у хворих на ЦД 2-го типу. Зокрема, для багатьох із них інсулінотерапія $\epsilon$ не останньою надією, а оптимальним із наявних в арсеналі варіантом терапії. Це пов'язано з тим, що адекватне зниження глікемії сприяє гальмуванню процесів глюконеогенезу в печінці, зменшенню рівня глікованого гемоглобіну, процесів глюкозотоксичності та навантаження на бета-клітини підшлункової залози, що в кінцевому підсумку призведе до зниження ризику макро- та мікросудинних ускладнень [11].

Сьогодні багато говорять про індивідуалізацію гіпоглікемічної терапії з урахуванням віку пацієнта, тривалості ЦД 2-го типу, глікемії та показників 
глікованого гемоглобіну. Причому у веденні таких пацієнтів важливо не допускати епізодів гіпоглікемії, які прямо корелюють зі смертністю [12]. Нині на світовому фармацевтичному ринку представлено безліч препаратів інсуліну, що дає лікареві можливість індивідуалізувати та оптимізувати інсулінотерапію для досягнення адекватного глікемічного контролю.

Метою даного дослідження було вивчення тривалої ефективності та стерпності всіх типів препаратів Фармасулін у хворих на ЦД 2-го типу.

Під спостереженням були 50 хворих, які проходили стаціонарне лікування у діабетологічному відділі ДУ «Інститут ендокринології та обміну речовин ім. В.П. Комісаренка НАМН України». Хворі для проходження курсу лікування госпіталізувалися 1 раз на рік. Період спостереження склав від 1,5 до 3,3 року, у середньому - 2,8 $\pm 1,2$ року.

Пацієнтів розподілили на дві групи: першу склали 30 хворих, які приймали Фармасулін Н і Фармасулін HNP, другу - 20 пацієнтів, які лікувалися препаратом Фармасулін Н30/70.

До першої групи увійшли 8 чоловіків та 22 жінки віком від 49 до 70 років (у середньому 64,06士3,84 року), з тривалістю цукрового діабету від 0,1 місяця до 23 років (у середньому 15,25士

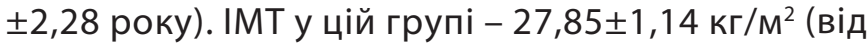

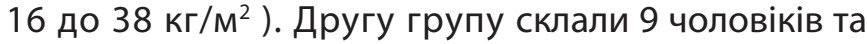
11 жінок віком від 54 до 70 років (середній вік $68,4 \pm 3,08$ року), середня тривалість захворювання

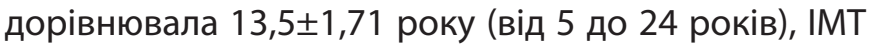

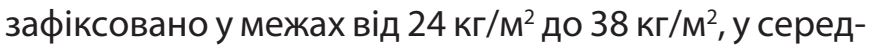

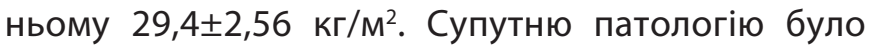
представлено такими захворюваннями: IXC, атеросклероз аорти та коронарних судин - 26 пацієнтів, хронічний пієлонефрит у стадії стійкої ремісії - 6 хворих, гіпертонічна хвороба - 29 осіб, у 6 хворих була патологія щитоподібної залози у вигляді змішаного зоба у стані евтиреозу.

Пацієнтам, які раніше приймали інсуліни, призначали відповідну дозу досліджуваних препаратів Фармасулін Н, Фармасулін НNP, Фармасулін Н30/70. Контролювали режим харчування хворих, не допускали пропускання приймань їжі. Крім того, контролювали режим фізичних навантажень. За необхідністю добову дозу препаратів і режим їх введення корегували. Корекцію дози проводили під постійним контролем глікемії, глюкозурії, кетонурії та здійснювали поступово до досягнення адекватної глікемії.

Питання про корекцію дози препаратів розглядали у таких випадках:
- погіршення загального стану хворих: гіперглікемія, полідипсія, поліурія, ніктурія, свербіж шкіри та геніталій, гіпоглікемічні стани;

- кетонурія, зміна маси тіла хворого, зміни способу життя хворого;

- інші чинники, які могли б призвести до підвищення ризику виникнення гіпоглікемій або гіперглікемій.

У першій групі 14 та у другій групі 13 пацієнтам інсулін було призначено вперше.

У пацієнтів визначали такі параметри: глікемію натще; глікемію постпрандіальну; глікемічний профіль (4 рази за період дослідження, за необхідності частіше - у хворих, яким вперше призначено інсулін); глікований гемоглобін, добову глюкозурію, кетонурію, відносну щільність сечі, діурез. Виконували загальний аналіз крові: гемоглобін, еритроцити, кольоровий показник, лейкоцити (загальна кількість із формулою), ШОЕ; біохімічний аналіз крові: креатинін, холестерин, $\beta$-ліпопротеїни; аналіз сечі. Зміни лабораторних показників впродовж спостереження (відхиленняза межі норми) розцінювали як побічну дію.

Лабораторні показники обробляли статистично на ПК із використанням критерію Стьюдента (t) із визначенням вірогідності розходжень (p). Різницю показників вважали вірогідною за $р<0,05$.

Основні показники динаміки вуглеводного обміну у хворих обох груп наведено у таблицях 1 і 2.

Аналіз показників, наведених у таблиці 1, показує, що у першій групі хворих відбулося вірогідне зниження глікемії натще після першого року спостереження, потім вона утримувалася практично без змін протягом усього спостереження. Постпрандіальна глікемія вірогідно знизилася після першого року лікування, на другий рік підвищилася та залишалася в межах вихідного рівня до кінця спостереження. Добова глюкозурія вірогідно знижувалася через рік після початку лікування та залишалася в межах 1\% протягом трьох років. Діурез вірогідно не змінився протягом всіх років спостереження. Рівень глікованого гемоглобіну вірогідно зменшився після першого року лікування, після другого дещо підвищився та залишався у середньому близько 9\% протягом 3 років. Добова доза інсуліну вірогідно підвищилася лише на другий рік лікування і до кінця спостереження залишалася практично без змін. Саме неадекватно підібраною дозою препаратів інсуліну можна пояснити недосягнення адекватної компенсації у певної частини хворих, включених до дослідження. 
Основні показники вуглеводного обміну у хворих на цукровий діабет у процесі лікування

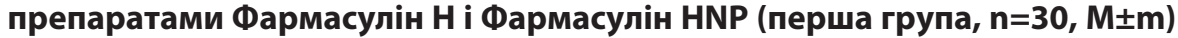

\begin{tabular}{lc|c|cc}
\multicolumn{1}{c|}{ Показник } & Початок спостереження & 1-й рік & 2-й рік & 3-й рік \\
\hline Глікемія натще, ммоль/л & $11,51 \pm 0,61$ & $8,95 \pm 0,67^{*}$ & $8,26 \pm 0,44^{*}$ & $7,81 \pm 0,60^{*}$ \\
\hline Глікемія постпрандіальна, ммоль/л & $10,64 \pm 1,13$ & $8,71 \pm 0,73^{*}$ & $10,07 \pm 1,21$ & $9,70 \pm 0,64$ \\
\hline Глюкозурія, г/л & $27,0 \pm 4,55$ & $12,76 \pm 4,8^{*}$ & $13,34 \pm 3,6^{*}$ & $10,7 \pm 2,77^{*}$ \\
\hline Діурез, л & $1,9 \pm 0,19$ & $1,73 \pm 0,16$ & $1,52 \pm 0,14$ & $1,56 \pm 0,18$ \\
\hline Добова доза інсулінів, ОД & $54,9 \pm 4,19$ & $60,7 \pm 4,12$ & $65 \pm 2,19^{*}$ & $61,7 \pm 4,19$ \\
\hline НьА1с, \% & $10,6 \pm 0,19$ & $8,7 \pm 0,75^{*}$ & $9,3 \pm 1,01$ & $8,9 \pm 1,24$ \\
\hline ІМТ, кг/м ${ }^{2}$ & $27,85 \pm 1,14$ & $29,76 \pm 0,19$ & $31,76 \pm 1,21^{*}$ & $31,98 \pm 1,87^{*}$ \\
\hline
\end{tabular}

Примітка: * - вірогідна різниця з показником на початку спостереження.

IMT поступово підвищувався протягом всього періоду дослідження, досягнувши вірогідного збільшення після двох років приймання препарату та залишався практично незмінним протягом третього року застосування інсуліну.

Аналіз показників, наведених у таблиці 2, показує, що у хворих другої групи, які приймали фіксовану суміш інсулінів, відбулося вірогідне зниження глікемії натще після першого року спостереження, потім вона утримувалася практично без змін протягом всього спостереження. Таку ж закономірність виявлено стосовно постпрандіальної глікемії. Постпрандіальна глікемія вірогідно знижувалася після першого року лікування та залишалася в межах зниженого рівня до кінця спостереження. Добова глюкозурія вірогідно знижувалася через рік лікування та залишалася в межах $1 \%$ протягом усіх трьох років. Діурез вірогідно не змінився протягом всіх років спостереження. Рівень глікованого гемоглобіну вірогідно зменшився після першого року лікування, залишався у середньому близько 8\% протягом 3 років лікування. Добова доза інсуліну вірогідно не змінювалася протягом всього дослідження. IMT залишався незмінним протягом трьох років дослідження.

Було виділено окремо групу хворих, яким вперше було призначено інсулін - 14 пацієнтів із першої групи та 13 пацієнтів із другої групи. Проаналізовано динаміку глікемії впродовж дня у період 21 день (табл. 3, 4).

Аналіз динаміки глікемії протягом дня та вірогідне зниження показників глікемії після лікування в обох групах свідчить про ефективну гіпоглікемізуючу дію застосованих препаратів

Табличя 2

\section{Основні показники вуглеводного обміну у хворих на цукровий діабет у процесі лікування}

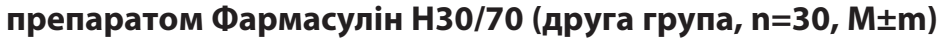

\begin{tabular}{lc|c|cc}
\multicolumn{1}{c}{ Показник } & Початок спостереження & 1-й рік & 2-й рік & 3-й рік \\
\hline Глікемія натще (ммоль/л) & $10,57 \pm 1,11$ & $8,55 \pm 0,97^{*}$ & $8,37 \pm 0,67^{*}$ & $8,29 \pm 0,98^{*}$ \\
\hline Глікемія постпрандіальна (ммоль/л) & $12,28 \pm 1,02$ & $9,01 \pm 0,97^{*}$ & $9,07 \pm 1,16^{*}$ & $9,46 \pm 0,89^{*}$ \\
\hline Глюкозурія (г/л) & $22,0 \pm 4,55$ & $14,56 \pm 5,1^{*}$ & $12,45 \pm 3,9^{*}$ & $11,1 \pm 2,56^{*}$ \\
\hline Діурез, л & $1,8 \pm 0,65$ & $1,56 \pm 023$ & $1,65 \pm 0,34$ & $1,45 \pm 0,34$ \\
\hline Добова доза інсулінів, ОД & $42,6 \pm 4,98$ & $46,2 \pm 3,54$ & $45 \pm 4,19$ & $49,7 \pm 3,75$ \\
\hline НЬА1с,\% & $10,8 \pm 0,29$ & $8,4 \pm 0,66^{*}$ & $8,4 \pm 1,01^{*}$ & $8,5 \pm 1,24 *$ \\
\hline ІМТ, кг/м ${ }^{2}$ & $29,4 \pm 2,56$ & $28,79 \pm 0,22$ & $30,01 \pm 1,41$ & $30,76 \pm 1,67$ \\
\hline
\end{tabular}

Примітка: * - вірогідна різниця з показником на початку спостереження. 
Глікемія протягом дня у хворих на цукровий діабет у процесі лікування препаратами Фармасулін Н і Фармасулін HNP

\begin{tabular}{|c|c|c|c|c|c|}
\hline \multirow{2}{*}{ Час } & \multirow{2}{*}{$\begin{array}{c}\text { Статистичний } \\
\text { показник }\end{array}$} & \multicolumn{4}{|c|}{ Основна група $(n=30)$} \\
\hline & & $\begin{array}{c}\text { Перед початком } \\
\text { лікування }\end{array}$ & 7-ма доба & 14-та доба & Після лікування \\
\hline $8^{00}$ & $\begin{array}{c}M \pm m \\
p\end{array}$ & $11,51 \pm 0,61$ & $8,95 \pm 0,67$ & $8,26 \pm 0,44$ & $\begin{array}{l}7,81 \pm 0,60 \\
\quad<0,05\end{array}$ \\
\hline $11^{00}$ & $\underset{p}{M \pm m}$ & $11,64 \pm 1,13$ & $10,71 \pm 0,73$ & $11,67 \pm 1,21$ & $\begin{array}{l}8,70 \pm 0,64 \\
\quad<0,05\end{array}$ \\
\hline $16^{00}$ & $\begin{array}{c}M \pm m \\
p\end{array}$ & $11,35 \pm 1,13$ & $10,75 \pm 0,80$ & $9,93 \pm 1,09$ & $\begin{array}{l}8,13 \pm 0,56 \\
\quad<0,05\end{array}$ \\
\hline $18^{00}$ & $\underset{p}{M \pm m}$ & $10,27 \pm 0,73$ & $10,94 \pm 0,86$ & $8,03 \pm 0,43$ & $\begin{array}{c}8,61 \pm 0,67 \\
>0,05<0,1\end{array}$ \\
\hline $21^{00}$ & $\begin{array}{c}M \pm m \\
p\end{array}$ & $10,86 \pm 1,23$ & $9,12 \pm 0,99$ & $7,98 \pm 0,53$ & $\begin{array}{c}7,72 \pm 0,58 \\
<0,05 \\
\end{array}$ \\
\hline
\end{tabular}

Примітка: $p$ - вірогідність різниці з показником на початку лікування.

інсуліну. Середня добова доза становила у хворих першої групи 42,53 $\pm 3,13$ ОД/добу, у хворих дру-

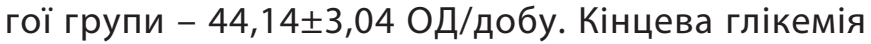
(21-й день лікування) не мала вірогідної різниці в обох групах пацієнтів, що $\epsilon$ ознакою спорідненої гіпоглікемізуючої ефективності випробовуваних інсулінів.

Гіпоглікемії як критерій ефективності інсуліну Фармасулін Н зафіксовано у 7 хворих, підтверджено лабораторно, і вони супроводжувалися суб'єктивними та об'єктивними проявами (виникненням раптового відчуття голоду, тремору, оніміння кінчика язика, пітливістю, слабкістю). Глікемія коливалася від 1,8 ммоль/л до 3,5 ммоль/л. 313 хворих, які приймали Фармасулін Н30/70, гіпоглікемії зафіксовані у 3, що супроводжувались аналогічною симпто- матикою та відповідали показникам від 1,9 ммоль/л до 4,0 ммоль/л. Майже в усіх випадках ступінь гіпоглікемій розцінено як легкий, адже стан не вимагав втручання інших осіб і корегувався вживанням вуглеводів. Лише одній хворій було введено 40 мл 10\% глюкози внутрішньовенно (глікемія 1,9 ммоль/л). Цукровий діабет у неї ускладнений діабетичною вегетативною полінейропатією, яка може маскувати прояви гіпоглікемії.

Лабораторні показники, наведені вище, підтверджувалися зменшенням кількості та вираженості характерних для діабету скарг, а саме: зменшенням або зникненням спраги, відчуття сухості у роті, поліурії, загальної слабкості та швидкої втомлюваності.

Показники загального аналізу крові перед

Глікемія протягом дня у хворих на цукровий діабет у процесі лікування препаратом Фармасулін Н30/70

\begin{tabular}{|c|c|c|c|c|c|}
\hline \multirow{2}{*}{ Час } & \multirow{2}{*}{$\begin{array}{c}\text { Статистичний } \\
\text { показник }\end{array}$} & \multicolumn{4}{|c|}{ Контрольна група $(n=30)$} \\
\hline & & $\begin{array}{c}\text { Перед початком } \\
\text { лікування }\end{array}$ & 7-ма доба & 14-та доба & Після лікування \\
\hline $8^{00}$ & $\begin{array}{c}M \pm m \\
p\end{array}$ & $12,4 \pm 1,06$ & $9,18 \pm 0,87$ & $9,51 \pm 0,81$ & $\begin{array}{l}9,20 \pm 0,81 \\
<0,05\end{array}$ \\
\hline $11^{00}$ & $\underset{p}{M \pm m}$ & $14,35 \pm 1,00$ & $11,24 \pm 0,90$ & $10,06 \pm 0,86$ & $\begin{array}{l}9,56 \pm 0,50 \\
\quad<0,05\end{array}$ \\
\hline $16^{00}$ & $\frac{M \pm m}{p}$ & $13,00 \pm 0,93$ & $10,60 \pm 0,59$ & $10,63 \pm 0,98$ & $\begin{array}{l}9,18 \pm 0,65 \\
<0,05\end{array}$ \\
\hline $18^{00}$ & $\frac{M \pm m}{p}$ & $11,67 \pm 0,96$ & $10,37 \pm 0,75$ & $10,11 \pm 0,78$ & $\begin{array}{l}8,21 \pm 0,35 \\
\quad<0,05\end{array}$ \\
\hline $21^{00}$ & $\underset{p}{M \pm m}$ & $10,90 \pm 1,02$ & $9,67 \pm 1,1$ & $7,86 \pm 0,62$ & $\begin{array}{l}8,39 \pm 0,83 \\
>0,05<0,1\end{array}$ \\
\hline
\end{tabular}

Примітка: $p$ - вірогідність різниці з показником на початку лікування. 
Основні показники загального аналізу крові у хворих перед початком і після лікування препаратами Фармасулін Н, Фармасулін HNP

\begin{tabular}{|c|c|c|c|}
\hline \multirow{2}{*}{ Показник } & \multicolumn{3}{|c|}{ Досліджувана група (n=30) } \\
\hline & Статистичний показник & Перед початком лікування & Після лікування \\
\hline $\begin{array}{l}\text { Гемоглобін } \\
\text { (г/л) }\end{array}$ & $\begin{array}{c}M \pm m \\
p\end{array}$ & $129,71 \pm 3,27$ & $\begin{array}{c}130,55 \pm 2,37 \\
>0,05\end{array}$ \\
\hline $\begin{array}{l}\text { Еритроцити } \\
\left(\times 10^{12} / л\right)\end{array}$ & $\begin{array}{c}M \pm m \\
p\end{array}$ & $3,32 \pm 0,17$ & $\begin{array}{c}3,42 \pm 0,11 \\
>0,05\end{array}$ \\
\hline $\begin{array}{l}\text { Лейкоцити } \\
\text { (×109/л) }\end{array}$ & $\underset{p}{\mathrm{M} \pm \mathrm{m}}$ & $6,2 \pm 0,41$ & $\begin{array}{c}5,1 \pm 0,21 \\
>0,05\end{array}$ \\
\hline $\begin{array}{l}\text { ШОЕ } \\
\text { (мм/год.) }\end{array}$ & $\underset{p}{\mathrm{M} \pm \mathrm{m}}$ & $15,22 \pm 1,80$ & $\begin{array}{c}17,42 \pm 2,07 \\
>0,05\end{array}$ \\
\hline
\end{tabular}

Примітка: $p$ - вірогідність різниці з показником на початку лікування.

початком і після лікування препаратами наведено у табл. 5, 6. Ці показники коливалися в межах норми та істотно не змінилися впродовж випробування.

Показники біохімічного аналізу крові пацієнтів обох груп за період дослідження вірогідно не змінилися (табл. 7, 8).

У загальному аналізі сечі в обох групах найбільш істотними були зміни показників глюкозурії та відносної щільності, а саме: зниження рівня глюкози $з$ 64,0 г/л (максимальний показник) на початку лікування до аглюкозурії (мінімальний показник у 12 хворих першої та у 10 хворих другої групи) після лікування. Відбулося зменшення відносної щільності з 1035 до 1008 в основній і з 1038 до 1010 у контрольній групах. Вірогідних змін протеїнурії, лейкоцитурії, еритроцитурії, мікроскопії осаду після лікування препаратами у більшості хворих не відзначено.

Динаміка скарг, характерних для ускладнень цукрового діабету і нехарактерних для цукрового діабету взагалі, в обох групах пацієнтів була також позитивною на тлі супутньої терапії.

Стосовно ускладнень ЦД слід відзначити, що за період 3-річного спостереження двоє хворих першої групи перенесли інфаркт міокарда, в однієі хворої другої групи був констатований синдром діабетичної стопи з виразкою на великому пальці, яка за 1 місяць загоїлася. Відміни інсулінів або значної зміни дози інсулінів у цих хворих не було.

Стерпність препаратів Фармасулін Н і Фармасулін HNP, Фармасулін Н30/70 оцінювали на підставі суб'єктивних скарг хворих, даних клінічного обстеження органів і систем пацієнтів 3 урахуванням динаміки лабораторних показників, наявності та характеру побічних явищ.

За результатами аналізу застосування препаратів Фармасулін Н і Фармасулін НNP, Фармасулін Н30/70 жодних алергічних, гастроентерологічних, гематологічних, неврологічних побічних явищ відзначено не було.

Основні показники загального аналізу крові у хворих перед початком і після лікування

Табличя 6 препаратом Фармасулін H30/70

\begin{tabular}{|c|c|c|c|}
\hline \multirow{2}{*}{ Показник } & \multicolumn{3}{|c|}{ Контрольна група група (n=30) } \\
\hline & Статистичний показники & Перед початком лікування & Після лікування \\
\hline $\begin{array}{l}\text { Гемоглобін } \\
\text { (г/л) }\end{array}$ & $\underset{p}{M \pm m}$ & $132,2 \pm 4,22$ & $\begin{array}{c}132,0 \pm 4,74 \\
>0,05\end{array}$ \\
\hline $\begin{array}{l}\text { Еритроцити } \\
\left(\times 10^{12} / л\right)\end{array}$ & $\underset{p}{M \pm m}$ & $3,21 \pm 0,19$ & $\begin{array}{c}3,01 \pm 0,12 \\
>0,05\end{array}$ \\
\hline $\begin{array}{l}\text { Лейкоцити } \\
\left(\times 10^{9} / л\right)\end{array}$ & $\underset{p}{M \pm m}$ & $6,34 \pm 0,23$ & $\begin{array}{c}5,84 \pm 0,56 \\
>0,05\end{array}$ \\
\hline $\begin{array}{l}\text { ШОЕ } \\
\text { (мм/год.) }\end{array}$ & $\begin{array}{c}M \pm m \\
p\end{array}$ & $14,88 \pm 2,2$ & $\begin{array}{c}15,05 \pm 2,4 \\
>0,05\end{array}$ \\
\hline
\end{tabular}

Примітка: $p$ - вірогідність різниці з показником на початку лікування. 
Основні біохімічні показники крові у хворих перед початком і після лікування препаратами Фармасулін Н, Фармасулін HNP

\begin{tabular}{|c|c|c|c|}
\hline \multirow{2}{*}{ Показник } & \multicolumn{3}{|c|}{ Основна група (n=30) } \\
\hline & Статистичний показники & Перед початком лікування & Після лікування \\
\hline $\begin{array}{l}\text { Холестерин } \\
\text { (ммоль/л) }\end{array}$ & $\frac{M \pm m}{p}$ & $5,70 \pm 0,26$ & $\begin{array}{l}5,73 \pm 0,33 \\
\quad>0,05\end{array}$ \\
\hline $\begin{array}{l}\text { Бета-ліпопротеїни } \\
\text { (ммоль/л) }\end{array}$ & $\underset{p}{M \pm m}$ & $4,90 \pm 0,19$ & $\begin{array}{l}4,20 \pm 0,27 \\
\quad>0,05\end{array}$ \\
\hline $\begin{array}{l}\text { Креатинін } \\
\text { (ммоль/л) }\end{array}$ & $\underset{p}{M \pm m}$ & $0,072 \pm 0,001$ & $\begin{array}{c}0,067 \pm 0,003 \\
>0,05\end{array}$ \\
\hline
\end{tabular}

Примітка: $p$ - вірогідність різниці з показником на початку лікування.

Основні біохімічні показники крові у хворих перед початком і після лікування

Табличя 8 препаратом Фармасулін H30/70

\begin{tabular}{|c|c|c|c|}
\hline \multirow{2}{*}{ Показник } & \multicolumn{3}{|c|}{ Контрольна група (n=30) } \\
\hline & Статистичний показники & Перед початком лікування & Після лікування \\
\hline $\begin{array}{l}\text { Холестерин } \\
\text { (ммоль/л) }\end{array}$ & $\begin{array}{c}M \pm m \\
p\end{array}$ & $6,80 \pm 0,31$ & $\begin{array}{l}7,1 \pm 0,40 \\
>0,05\end{array}$ \\
\hline $\begin{array}{l}\text { Бета-ліпопротеїни } \\
\text { (ммоль/л) }\end{array}$ & $\underset{p}{M \pm m}$ & $5,00 \pm 0,19$ & $\begin{array}{l}3,8 \pm 0,21 \\
>0,05\end{array}$ \\
\hline $\begin{array}{l}\text { Креатинін } \\
\text { (ммоль/л) }\end{array}$ & $\begin{array}{c}M \pm m \\
p\end{array}$ & $0,077 \pm 0,005$ & $\begin{array}{c}0,073 \pm 0,006 \\
>0,05\end{array}$ \\
\hline
\end{tabular}

Примітка: $p$ - вірогідність різниці з показником на початку лікування.

Отже, сукупність наведених даних дає можливість стверджувати про безпечність препаратів Фармасулін Н і Фармасулін HNP, Фармасулін Н30/70 у лікуванні хворих на ЦД 2-го типу, яким необхідно проведення інсулінотерапії.

\section{ЛITEPATУPA}

1. IDF (International Diabetes Federation). Diabetes Atlas 5th Edition. 2011.

2. Unwin N., Whiting D., Roglic G. Social determinants of diabetes and challenges of prevention. Lancet. 2010; 375 (9733): 2204-2205.

3. Mercer B.N., Morais S., Cubbon R.M., Kearney M.T. Diabetes mellitus and the heart. Int J Clin Pract. 2012; 66 (7): 640-647.

4. Результаты реализации подпрограммы «Сахарный диабет» федеральной целевой программы «Предупреждение и борьба с социально значимими заболеваниями 2007-2012 годы». Ред. И.И. Дедов, М.В. Шестаковой, М.: ЭНЦ, 2012. - 52 c.

5. Stration M., Adlet A.l., Neil H.A. et al. Association of glycaemia with macrovascular and microvascular complications of type 2 diabetes (UKPDS 35). BMJ. 2000; 321: 405-412.

6. Дедов И.И., Шестакова М.В., Аметов А.С. и др. Консенсус сонета экспертов Российской Ассоциации эндокринологов (РАЭ) по инициации и интен- сификации сахароснижающей терапии сахарного диабета 2 типа. Сахарный диабет. 2011; 4: 6-17.

7. Inzucchi S.E., Bergenstal R.M., Buse J.B. et al. Management of hyperglycemia in type 2 diabetes: a patientcentered approach: position statement of the American Diabetes Association (ADA) and the European Association for the Study of Diabetes (EASD). Diabetes Care. 2012; 35 (6): 1364-1379.

8. Соплевенко А.А., Аметов А.С. Особенности психоэмоционального состояния больных сахарным диабетом, получающих инсулинотерапию и другие сахароснижающие препараты. Клин фармакол. терапия. 2012; 21 (2): 74-78.

9. Vaag A., Lund S.S. Insulin initiation in patients with type 2 diabetes mellitus: treatment guidelines, clinical evidence and patterns of use of basal vsp remixed insulin analogues. Eur J Endocrinol. 2012; 166 (2): 159170.

10. Dale J., Martin S., Gadsby R. Insulin initiation in primary care for patients with type 2 diabetes: 3-year follow-up study. Primary Care. Diabetes 2010; 4: 85-89.

11. Ringborg A., Lindgren P., Yin D.D. et al. Time to insulin treatment and factors associated with insulin prescription in Swedish patients with type 2 diabetes. Diabetes and Metabolism 2010; 36: 198-203.

12. Инсулинотерапия при СД 2 типа: доказанные преимущества против надуманных барьеров. Avalable at http//www.dianews.ru/04/03/articles/04/01.shtm.

Дата надходження до редакції 10.01.2015 p. 